\title{
Comparative Evaluation of Fattening, Slaughter and Meat Qualities of Purebred and Hybrid Swine
}

\author{
Zhanna Aleksandrovna Perevoyko ${ }^{1}$ \\ ${ }^{1}$ Perm State Agricultural Academy named after academician D.N. Pryanishnikov, Russia \\ Correspondence: Zhanna Aleksandrovna Perevoyko, Perm State Agricultural Academy named after \\ academician D.N. Pryanishnikov, 23Petropavlovskaia st., 614990 Perm, Russia
}

Received: October 29, 2014

Accepted: November 12, 2014

Online Published: July 31, 2015

doi:10.5539/mas.v9n8p344

URL: http://dx.doi.org/10.5539/mas.v9n8p344

\begin{abstract}
The creation of more productive breeds, lines, types, and their rational use in purebred breeding and hybridization contributes to the efficiency of swine industry. Comparative study on meat quality of pigs is essential for an objective assessment of the bred species, lines, and hybrids. We carried out a study on the meat quality of purebred and hybrid pigs fattening up to $100 \mathrm{~kg}$ and $125 \mathrm{~kg}$ of live weight under the conditions of an industrial complex. It was established, that of higher nutritional value, as well as of good fattening qualities, was the meat of two-breed hybrids $\mathrm{LW} \times \mathrm{DL}$ and three-breed combinations $(\mathrm{LW} \times \mathrm{DL}) \times \mathrm{DIb}$ both fattening to100 $\mathrm{kg}$ and fattening to $125 \mathrm{~kg}$ of live weight.
\end{abstract}

Keywords: breed, breeding, hybridization, crossing, fattening qualities, meat quality, water binding ability

\section{Introduction}

\subsection{Introduce the Problem}

Shortage of animal protein in the diet of the population in the Russian Federation remains an important problem of food supply in the country. The main source of protein is meat. One of the most difficult and important problems to be addressed the agriculture of Russia is increase in production of meat, and first of all, pork as the most precocious livestock industry. Digestibility and bioavailability of swine meat in human's organism is $95 \%$. The uniqueness of the pig meat is its high energy content, balanced amino acid composition of proteins, the presence of biologically active substances and its high digestibility, all of which ensures the normal physical and mental human's activities (Babailova et al., 2010).

The main raw material for the production of high-quality meat products supply in most countries of the world remains the pork. Muscle tissue of pigs in comparison with beef contains three times bigger amount of polyunsaturated fatty acids, eight times more vitamin B1, has a soft texture and pleasant aroma and taste, so the food value of the pork is very high (Birta, 2008; Kortz \& Czarnecki, 1999).

Quality of pork is determined by the set of properties that provide nutritional value of products, taste and nutritional properties. Pork quality management is a very complex, laborious and multifactorial process. In this regard, focused selection remains the most effective way (Burmistrov \& Pustovit, 2005, Okolyshev, 2008).

\subsection{Explore Importance of the Problem}

Priority direction in modern swine production is breeding pigs to increase the muscle mass. The main factor of improving the fattening and meat qualities of pigs is usage of the best selection options of specialized lines and breeds to produce hybrids.

\subsection{State Hypotheses and Their Correspondence to Research Design}

In young swine obtained as a result of two-and three-breed hybridization, the heterosis effect appears constantly. Two-and three- breed young animals have a higher precocity, adaptation flexibility and are better adapted to breeding at swine production complexes than purebred peers (DuninI et al., 2009; Kabanov \& Titov, 2013; Ovchinnikov \& Zatsarinin, 2013).

The difficulty of breeding to increase the quantity and improve the quality of the meat is that these rates negatively correlate with each other. Therefore, breeding pigs on meat must be accompanied by complex assessment of the quality of meat after slaughter of animals (Pogodaev \& Peshkov, 2011, Rybalko et al., 2011). 
Currently, requirements for quantity and quality of meat are growing. Therefore, methods of increasing the muscle mass in swine are of particular importance.

On this basis, the aim of our study was to examine the quality of the meat of pigs, produced by purebred and breeding of three-breed hybridization in fattening to $100 \mathrm{~kg}$ and $125 \mathrm{~kg}$ of live weight under conditions of an industrial complex.

\section{Methods}

All studies in the period of experiment were conducted using conventional methods.

\subsection{Participant (Subject) Characteristics}

To conduct the investigation under the principle of analogue groups dependent on the origin we formed 10 groups of yelts -15 animals in each group on the following scheme: the first group - control group- LW $\times$ LW; $2^{\text {nd }}-10^{\text {th }}-$ experimental groups: $2^{\text {nd }}-\mathrm{LW} \times \mathrm{D}$, the $3^{\text {rd }}$ group $-\mathrm{LW} \times \mathrm{DL}$, the $4^{\text {th }}$ group $-\mathrm{LW} \times \mathrm{FL}$, the $5^{\text {th }}-\mathrm{LW}$ $\times \mathrm{B} \mathrm{b} / \mathrm{w}$, the $6^{\text {th }}$ group $(\mathrm{LW} \times \mathrm{DL}) \times \mathrm{D}$, the $7^{\text {th }}$ group $(\mathrm{LW} \times \mathrm{DL}) \times \mathrm{Dib}$, the $8^{\text {th }}$ group $(\mathrm{LW} \times \mathrm{DL}) \times \mathrm{MG}$, the $9^{\text {th }}$ group $\mathrm{LW} \times(\mathrm{D} \times \mathrm{FL})$, the $10^{\text {th }}$ group $\mathrm{LW} \times(\mathrm{FL} \times \mathrm{D})$, where $\mathrm{LW}-$ Large White, $\mathrm{D}-$ Duroc, $\mathrm{DL}-\mathrm{Dutch}$ Landrace, FL - Finnish Landrace, Bb/w - Belarusian black-and-white, DIb - Duroc of the Irish breeding, MG synthetic line of the Irish breeding.

The experience was conducted in the OJSC "Perm pig farm" in Permskii krai.

\subsection{Sampling Procedures}

During the studies all the animals were held in the same conditions of feeding and keeping. All animals in the groups were fed with specialized combined feed for animals.

\subsubsection{Sample Size, Power, and Precision}

The evaluation of slaughter qualities was conducted on the results of control slaughter of swine at reaching 100 and $125 \mathrm{~kg}$ of live weight with the relevant studies of carcasses. In each group of slaughtered animals a full deboning of half carcass was conducted to obtain fair presentation of meat quality of pigs.

\subsubsection{Measures and Covariates}

For the qualitative study of muscle tissue at slaughter of pigs we took samples of longissimusdorsi on a site between 9-12 scapula vertebraes, 400g. Chemical analysis of meat was conducted by conventional methods of zoo-technical analysis. In addition, we identified $\mathrm{pH}$ by potentiometric method, the water-binding ability - by Grau-Gram press method in the VNIIMP modification. The results obtained were processed by means of variation statistics method by E.K. Merkurieva in Microsoft Excel programme.

\section{Results}

Scientific and economic experience was held in the timeframe 2013-2014 with two-and three-breed hybrids young. Basic study on feeding, meat and meat qualities were held during the period of the fattening, within 100 days, and when the young pigs were send to a meat-processing plant.

\subsection{Recruitment}

Creation of highly productive hybrids or crosses involves, above all, improving the genetic potential of the source breeds, types, lines, consolidations of their basic productivity qualities, breeding for the compatibility. (Bekenev, 2012).

\subsection{Statistics and Data Analysis}

It is known that in swine of different breeds, the heritability of features such as average daily gain and feed consumption is quite high (average daily gain of $0.31-0.77$, feed consumption per $1 \mathrm{~kg}$ of gain $-0.2-0.5$ ), fattening qualities have the average value of heritability, and meat qualities - high. It is therefore considered that the increase in the intensity of growth must be based on the relevant conditions of feeding and keeping, taking into account the formation of strong type of animals. (Zhebrovskii, 2002; Lesley, 1982; Bazhov, 2006).

The indicators that determine the intensity of swine husbandry are feed consumption per unit of gain, earliness and growth speed. Among two-breed crossing options, yelts LW $\times$ DL reached $100 \mathrm{~kg}$ of live weight in 182.1 days; that was the minimum age. They surpassed by precocity the purebred animals on 9.1 days, analogues of other two-breed combinations on 2.1-10.2 days (table 1). 
Table 1. Fattening qualities of purebred and mixed young

\begin{tabular}{lllll}
\hline \multirow{2}{*}{ Group } & $\begin{array}{l}\text { Hybridization } \\
\text { variant }\end{array}$ & \multicolumn{3}{c}{ Indicator } \\
\cline { 3 - 5 } & & $\begin{array}{l}\text { Age of gaining live } \\
\text { weight } 100 \mathrm{~kg} \text {, days }\end{array}$ & $\begin{array}{l}\text { Average gain a } \\
\text { day, g }\end{array}$ & $\begin{array}{l}\text { Feed consumption per 1 } \\
\text { kg of gain, feed unit }\end{array}$ \\
\hline I & $\mathrm{LW} \times \mathrm{LW}$ & $191.2 \pm 1.48$ & $674.7 \pm 5.94$ & $4.22 \pm 0.11$ \\
II & $\mathrm{LW} \times \mathrm{D}$ & $186.6 \pm 2.20$ & $712.8 \pm 4.32^{* * *}$ & $3.87 \pm 0.03^{* * *}$ \\
III & $\mathrm{LW} \times \mathrm{DL}$ & $182.1 \pm 1.84^{* *}$ & $735.8 \pm 6.21^{* * *}$ & $3.89 \pm 0.03^{* * *}$ \\
IV & $\mathrm{LW} \times \mathrm{FL}$ & $184.2 \pm 1.34^{* *}$ & $724.3 \pm 4.44^{* *}$ & $3.92 \pm 0.02^{* * *}$ \\
V & $\mathrm{LW} \times \mathrm{Bb} / \mathrm{w}$ & $192.3 \pm 2.17$ & $667.3 \pm 4.15$ & $4.31 \pm 0.12$ \\
VI & $(\mathrm{LW} \times \mathrm{DL}) \times \mathrm{D}$ & $172.4 \pm 1.18^{* * *}$ & $761.2 \pm 6.06^{* * *}$ & $3.73 \pm 0.14^{* *}$ \\
VII & $(\mathrm{LW} \times \mathrm{DL}) \times \mathrm{DIb}$ & $168.5 \pm 2.11^{* * *}$ & $818.7 \pm 6.42^{* * *}$ & $3.68 \pm 0.13^{* * *}$ \\
VIII & $(\mathrm{LW} \times \mathrm{DL}) \times \mathrm{MG}$ & $167.8 \pm 1.92^{* * *}$ & $821.9 \pm 4.71^{* * *}$ & $3.62 \pm 0.15^{* *}$ \\
IX & $\mathrm{LW} \times(\mathrm{D} \times \mathrm{FL})$ & $172.9 \pm 1.63^{* * *}$ & $764.6 \pm 5.32^{* * *}$ & $3.71 \pm 0.12^{* * *}$ \\
$\mathrm{X}$ & $\mathrm{LW} \times(\mathrm{FL} \times \mathrm{D})$ & $173.4 \pm 2.08^{* * *}$ & $760.5 \pm 5.64^{* * *}$ & $3.77 \pm 0.13^{* *}$ \\
\hline
\end{tabular}

Note: - ${ }^{*} \mathrm{P}<0.05 ; * * \mathrm{P}<0.01 ; * * * \mathrm{P}<0.001$.

We established cross-group differences in the values of average daily weight gain. The mixed LW $\times$ DL had the highest intensity of growth from the beginning of the fattening until the weight of $100 \mathrm{~kg}$ among two-breed animals. The daily gains of body weight amounted to $735.8 \mathrm{~g}$. Two-breed LW $\times$ DL exceeded purebred pigs on this indicator on $61.1 \mathrm{~g}$ or $9.1 \%$ ( $\mathrm{p}>0.999$ ), two-breed peers - on $11.5-68.5 \mathrm{~g}$ or $1.5-10.3 \%$.

The main indicator of efficiency of fattening pig is feed consumption per $1 \mathrm{~kg}$ of gain. In the cost structure of pork feed constitutes the major share (about $70 \%$ ). It was found that two-breed animals $\mathrm{LW} \times \mathrm{D}, \mathrm{LW} \times \mathrm{DL}$ and $\mathrm{LW} \times \mathrm{FL}$ differed by less feed consumption per $1 \mathrm{~kg}$ of gain compared to purebred animals of Large White breed The difference was $0.35,0.33$ and 0.30 feeding units or $9.0 ; 8.5$ and $7.7 \%$ ( $>>0.999)$, respectively. The two-breed LW $\times$ D hybrids were characterized by the minimum feed consumption -3.87 feeding units.

The advantage of three-breed crossing compared to purebred breeding is distinguished through less feed consumption per gain in fattening offspring on 0.45-0.60 feeding units $(\mathrm{P}>0,999)$.

Fattening qualities of swine under experiment were also estimated by the quality and age of reaching $125 \mathrm{~kg}$ of live weight, the average daily weight gains and feed consumption per $1 \mathrm{~kg}$ of body mass gains (table 2).

The analysis of the data shows that the best qualities of feeding among two-breed crossed options were in mixed animals LW $\times$ DL. They reached the $125 \mathrm{~kg}$ of live weight 11.8 days earlier than the pure-bred peers, surpassed them on average daily gain on $57.8 \mathrm{~g}$ two-breed $\mathrm{LW} \times \mathrm{DL}$ and $\mathrm{LW} \times \mathrm{FL}$ had better pay for feed -4.35 feed units.

The advantage of three-breed animals $(\mathrm{LW} \times \mathrm{DL}) \times$ DIb over the purebred animals of Large White breed in age of reaching $125 \mathrm{~kg}$ of live weight constituted 16.7 and 17.7 days, in average daily gain -85.0 and $90.8 \mathrm{~g}$, in feed consumption -0.60 and 0.67 feeding units, respectively.

Main indicators of quality meat carcasses are: length, thickness and lard smoothness, muscle eye size and mass of the rear third of half carcass. These indicators are used for evaluating meat and slaughter qualities both in Russia and abroad.

Table 2. Fattening qualities of offspring reaching $125 \mathrm{~kg}$ of live weight

\begin{tabular}{|c|c|c|c|c|}
\hline \multirow[b]{2}{*}{ Group } & \multirow{2}{*}{$\begin{array}{l}\text { Hybridization } \\
\text { variant }\end{array}$} & \multicolumn{3}{|c|}{ Indicator } \\
\hline & & $\begin{array}{l}\text { Age of reaching live } \\
\text { weight } 125 \mathrm{~kg} \text {, days }\end{array}$ & $\begin{array}{l}\text { Daily average } \\
\text { gain, } g\end{array}$ & $\begin{array}{l}\text { Food consumption } \\
\text { per } 1 \mathrm{~kg} \text { of gain, } \\
\text { feed unit }\end{array}$ \\
\hline I & $\mathrm{LW} \times \mathrm{LW}$ & $235.2 \pm 1.84$ & $654.3 \pm 7.12$ & $4.76 \pm 0.13$ \\
\hline II & $\mathrm{LW} \times \mathrm{D}$ & $229.6 \pm 2.11$ & $680.5 \pm 6.43 * * *$ & $4.37 \pm 0.18$ \\
\hline III & $\mathrm{LW} \times \mathrm{DL}$ & $223.4 \pm 1.14 * * *$ & $712.1 \pm 7.12 * * *$ & $4.35 \pm 0.19$ \\
\hline IV & $\mathrm{LW} \times \mathrm{FL}$ & $226.3 \pm 1.18 * * *$ & $696.9 \pm 7.40 * * *$ & $4.35 \pm 0.11 *$ \\
\hline V & $\mathrm{LW} \times \mathrm{Bb} / \mathrm{w}$ & $236.5 \pm 1.23$ & $648.5 \pm 8.12$ & $4.87 \pm 0.17$ \\
\hline VI & $(\mathrm{LW} \times \mathrm{DL}) \times \mathrm{D}$ & $223.8 \pm 1.82 * * *$ & $710.0 \pm 8.82 * * *$ & $4.18 \pm 0.16^{* *}$ \\
\hline VII & $\begin{array}{l}(\mathrm{LW} \times \mathrm{DL}) \times \\
\mathrm{DIb}\end{array}$ & $218.5 \pm 1.95 * * *$ & $739.3 \pm 8.92 * * *$ & $4.16 \pm 0.10^{* *}$ \\
\hline
\end{tabular}




\begin{tabular}{lllll}
\hline VIII & $(\mathrm{LW} \times \mathrm{DL}) \times$ & $217.5 \pm 2.14^{* * *}$ & $745.1 \pm 7.14^{* * *}$ & $4.09 \pm 0.13^{* *}$ \\
& $\mathrm{MG}$ & & & \\
$\mathrm{IX}$ & $\mathrm{LW} \times(\mathrm{D} \times \mathrm{FL})$ & $224.5 \pm 1.80^{* * *}$ & $706.3 \pm 7.94^{* * *}$ & $4.19 \pm 0.20^{*}$ \\
$\mathrm{X}$ & $\mathrm{LW} \times(\mathrm{FL} \times \mathrm{D})$ & $225.2 \pm 1.75^{* * *}$ & $701.1 \pm 8.01^{* * *}$ & $4.18 \pm 0.18^{*}$ \\
\hline
\end{tabular}

Note: $-* \mathrm{P}<0.05 ; * * \mathrm{P}<0.01 ; * * * \mathrm{P}<0.001$

Meat qualities in swine are determined by a number of factors: conditions of feeding and housing, fatness, age and weight of an animal at slaughter, gender, breed, individual features (genotype), growth pace, what can be explained by the change of the organs and tissue growth character and exchange processes during the growth and development of an animal. In addition, meat qualities of swine in many aspects depend on breed, crossing variants of different genotypes, stress sensitivity and a number of other factors (Perevoiko, 2005; Matoušk et al., 1997; Mucami \& Jamada, 1992).

Crossing sows of Large White breed with boars of meat breeds (Landrace and Duroc) and mixed boars is one of the ways to improve the meat qualities of the fattening young animals in conditions of industrial swine production. The degree of influence of meat breeds on the formation of the muscle mass in mixed livestock was confirmed by the results of slaughter and deboning of carcasses of swine when they reach 100 and $125 \mathrm{~kg}$ of live weight.

It is established that at slaughter in $100 \mathrm{~kg}$, half carcasses of two-breed piglets were longer than of purebred (table 3).

Table 3. Meat qualities of offspring at slaughter in $100 \mathrm{~kg}$

\begin{tabular}{|c|c|c|c|c|c|}
\hline \multirow[b]{2}{*}{ Group } & \multirow{2}{*}{$\begin{array}{l}\text { Hybridization } \\
\text { variant }\end{array}$} & \multicolumn{4}{|c|}{ Indicator } \\
\hline & & $\begin{array}{l}\text { Half carcass length, } \\
\mathrm{cm}\end{array}$ & $\begin{array}{l}\text { Fat thickness, } \\
\mathrm{cm}\end{array}$ & $\begin{array}{l}\text { Muscle eye } \\
\text { area, } \mathrm{cm}^{2}\end{array}$ & $\begin{array}{l}\text { Mass ham, } \\
\mathrm{kg}\end{array}$ \\
\hline I & $\mathrm{LW} \times \mathrm{LW}$ & $95.2 \pm 1.33$ & $2.33 \pm 0.24$ & $39.5 \pm 1.23$ & $8.0 \pm 0.31$ \\
\hline II & $\mathrm{LW} \times \mathrm{D}$ & $94.9 \pm 2.14$ & $2.27 \pm 0.15$ & $44.7 \pm 1.12 *$ & $10.5 \pm 0.23^{* * *}$ \\
\hline III & $\mathrm{LW} \times \mathrm{DL}$ & $103.9 \pm 1.68 * *$ & $2.12 \pm 0.19$ & $46.2 \pm 1.73 *$ & $10.9 \pm 0.23^{* * *}$ \\
\hline IV & $\mathrm{LW} \times \mathrm{FL}$ & $98.2 \pm 1.86$ & $2.25 \pm 0.22$ & $45.3 \pm 1.73 *$ & $10.8 \pm 0.38^{* * *}$ \\
\hline V & $\mathrm{LW} \times \mathrm{Bb} / \mathrm{w}$ & $96.5 \pm 0.91$ & $2.76 \pm 0.22$ & $38.6 \pm 0.94$ & $8.7 \pm 0.16$ \\
\hline VI & $(\mathrm{LW} \times \mathrm{DL}) \times \mathrm{D}$ & $98.9 \pm 1.69$ & $2.18 \pm 0.17$ & $60.0 \pm 4.36^{* *}$ & $10.0 \pm 0.54^{*}$ \\
\hline VII & $(\mathrm{LW} \times \mathrm{DL}) \times \mathrm{DIb}$ & $102.4 \pm 1.29 * *$ & $1.96 \pm 0.25$ & $63.5 \pm 4.63 * * *$ & $12.4 \pm 0.24 * * *$ \\
\hline VIII & $(\mathrm{LW} \times \mathrm{DL}) \times \mathrm{MG}$ & $101.6 \pm 1.28^{*}$ & $2.10 \pm 0.08$ & $61.4 \pm 2.88 * * *$ & $12.1 \pm 0.32 * * *$ \\
\hline IX & $\mathrm{LW} \times(\mathrm{D} \times \mathrm{FL})$ & $99.4 \pm 1.50$ & $2.24 \pm 0.11$ & $59.7 \pm 2.73 * * *$ & $10.0 \pm 0.35^{*}$ \\
\hline $\mathrm{X}$ & $\mathrm{LW} \times(\mathrm{FL} \times \mathrm{D})$ & $100.4 \pm 2.50$ & $1.96 \pm 0.19$ & $58.5 \pm 2.21 * * *$ & $10.3 \pm 0.72 *$ \\
\hline
\end{tabular}

Note: $-* \mathrm{P}<0.05 ; * * \mathrm{P}<0.01 ; * * * \mathrm{P}<0.001$.

The length of the half carcass of piglets in these groups ranged from $94.9 \mathrm{~cm}$ to $103.9 \mathrm{~cm}$. Half carcasses of piglets $\mathrm{LW} \times \mathrm{DL}$ were the longest, they exceeded the purebred offspring $\mathrm{LW} \times \mathrm{LW}$ on the investigated indicator on $8.7 \mathrm{~cm}(\mathrm{P}>0.99)$.

Therefore, the greatest increase in the length of the half carcass in the options of two-breed mating was observed when using landrace breeds of Dutch selection.

The analysis of the data shows that half carcasses of swine LW $\times$ DL had the smallest thickness of lard over 6-7 pectoral vertebrae of two-breed animals at slaughter in $100 \mathrm{~kg}$, and amounted to $2.12 \mathrm{~cm}$, that is lower than the figures of $\mathrm{LW} \times \mathrm{DL}$ on $0.21 \mathrm{~cm}$.

One of the main indicators characterizing meat quality of pigs is muscle eye area. It was found that mixed animals LW $\times$ DL at slaughter in $100 \mathrm{~kg}$ exceeded the two-breed analogues and Large White breed on 0.9-7.6 and $6.7 \mathrm{~cm}^{2}$ or on $1.98-19.6$ and $16.9 \%$, respectively.

The back third of half carcass is the most valuable part in term of food. Therefore, the quality of carcass depends on the mass of the back ham and its morphological content.

Based on the obtained data, the substantial differences between the animals of the test and control groups can be noted. The greater weight of the back leg of two-breed crossing options were hybrids $\mathrm{LW} \times \mathrm{DL}-10.9 \mathrm{~kg}$, what is 
on $2.9 \mathrm{~kg}$ or $36.3 \%$ more than that of purebred animals $(\mathrm{P}>0.999)$ and $0.1-2.2$ or $0.9-25.3 \%$ than in two-breed analogues.

The evaluation of the half carcass of two-breed hybrids and purebred animals has shown that the most noticeable meat qualities were in two-breed animals $\mathrm{LW} \times \mathrm{DL}, \mathrm{LW} \times \mathrm{FL}$ and $\mathrm{LW} \times \mathrm{D}$ with thin lard, large area of the muscle eye and ham mass.

In three-breed hybrids compared to purebred peers of Large White breed at slaughter in $100 \mathrm{~kg}$, the half carcass is on 3.7-7.2 cm longer or on 3.9-7.6\% longer, muscle eye area - on $19.0-24.0 \mathrm{~cm}^{2}$ or on $51.1-60.8 \%$, ham muss - on $2.0-4.4 \mathrm{~kg}$ or on $25.0-55.0 \%$, and lard is thinner on $0.09-0.37 \mathrm{~mm}$ or on $4-37.0 \%$.

At slaughter of fattening swine in $125 \mathrm{~kg}$ of live weight among two-breed crossing options, the carcasses of offspring LW $\times$ DL were characterized by thinner lard $(2.39 \mathrm{~cm})$, larger muscle eye area $\left(48.3 \mathrm{~cm}^{2}\right)$; their parameters exceeded analogue indicators at slaughter in $100 \mathrm{~kg}$ on 12.7 and $4.5 \%$, respectively (table 4 ).

Table 4. Meat qualities of offspring at slaughter in $125 \mathrm{~kg}$

\begin{tabular}{llllll}
\hline \multirow{2}{*}{ Group } & Hybridization & \multicolumn{4}{c}{ Indicator } \\
\cline { 3 - 6 } & & $\begin{array}{l}\text { Length of half } \\
\text { carcass, cm }\end{array}$ & $\begin{array}{l}\text { Lard } \\
\text { thickness, cm }\end{array}$ & $\begin{array}{l}\text { Muscle eye } \\
\text { area, } \mathrm{cm}^{2}\end{array}$ & Mass ham, kg \\
I & LW $\times$ LW & $97.0 \pm 1.32$ & $2.70 \pm 0.13$ & $41.7 \pm 1.12$ & $8.3 \pm 0.22$ \\
II & LW $\times$ D & $97.3 \pm 2.14$ & $2.56 \pm 0.14$ & $46.8 \pm 1.32^{*}$ & $10.8 \pm 0.35^{* *}$ \\
III & LW $\times$ DL & $106.6 \pm 1.24^{* *}$ & $2.39 \pm 0.39$ & $48.3 \pm 1.62^{*}$ & $11.2 \pm 0.34^{* * *}$ \\
IV & LW $\times$ FL & $101.0 \pm 1.52$ & $2.40 \pm 0.16$ & $47.7 \pm 1.71^{*}$ & $11.1 \pm 0.26^{* * *}$ \\
V & LW $\times \mathrm{Bb} / \mathrm{w}$ & $98.8 \pm 1.78$ & $3.02 \pm 0.12$ & $40.6 \pm 0.83$ & $9.0 \pm 0.96$ \\
VI & $(\mathrm{LW} \times \mathrm{DL}) \times \mathrm{D}$ & $102.0 \pm 1.58$ & $2.00 \pm 0.15^{*}$ & $62.0 \pm 1.68^{* * *}$ & $10.0 \pm 0.83$ \\
VII & $(\mathrm{LW} \times \mathrm{DL}) \times \mathrm{DIb}$ & $104.8 \pm 1.18^{* *}$ & $2.23 \pm 0.18$ & $65.5 \pm 1.62^{* * *}$ & $12.7 \pm 0.34^{* * *}$ \\
VIII & $(\mathrm{LW} \times \mathrm{DL}) \times \mathrm{MG}$ & $103.6 \pm 1.17^{*}$ & $2.35 \pm 0.21$ & $63.4 \pm 1.58^{* * *}$ & $12.2 \pm 0.41^{* * *}$ \\
IX & $\mathrm{LW} \times(\mathrm{D} \times \mathrm{FL})$ & $98.0 \pm 1.61$ & $2.40 \pm 0.21$ & $61.7 \pm 1.63^{* * *}$ & $10.4 \pm 0.44^{* *}$ \\
$\mathrm{X}$ & $\mathrm{LW} \times(\mathrm{FL} \times \mathrm{D})$ & $105.0 \pm 1.49^{* *}$ & $2.20 \pm 0.28$ & $60.7 \pm 1.51^{* * *}$ & $10.6 \pm 0.62^{* *}$ \\
\hline
\end{tabular}

Note: $-* \mathrm{P}<0.05$; ** $\mathrm{P}<0.01 ; * * * \mathrm{P}<0.001$

Two-breed and three-breed hybrids at slaughter in $125 \mathrm{~kg}$ exceeded the analogues at slaughter in $100 \mathrm{~kg}$ on the length of half carcass, muscle eye area and ham mass; however, they were lower on lard thickness in average $0.23 \mathrm{~cm}$ or $9.7 \%$ (two-breed hybrids) and $0.15 \mathrm{~cm}$ on $7.2 \%$ (three-breed hybrids).

The most noticeable meat qualities at slaughter in $125 \mathrm{~kg}$ were three-breed animals $(\mathrm{LW} \times \mathrm{DL}) \times \mathrm{DIb}$ that had the longest half carcass $-104.8 \mathrm{~cm}$, the largest area of the muscle eye $-65.5 \mathrm{~cm}^{2}$ with the smallest thickness of back fat over 6-7 breast vertebra $-2.23 \mathrm{~cm}$.

The slaughter output is a summarized indicator of swine slaughter qualities which decreases from $73-84 \%$ to $62-71 \%$ in the first three months after birth, and in subsequent age periods increases to $78-81 \%$ (Kabanov V. et al,Titov I., 2013).

At slaughter of two-breed hybrids of $100 \mathrm{~kg}$ of live weight it was established that the mass of fresh carcass in hybrids $\mathrm{LW} \times \mathrm{FL}$ is higher in comparison to the analogues of the control group $\mathrm{LW} \times \mathrm{LW}$ on $0.9 \mathrm{~kg}$ or on $1.4 \%$ (table 5).

Table 5. Slaughter qualities of offspring at slaughter in $100 \mathrm{~kg}$

\begin{tabular}{|c|c|c|c|c|c|c|c|}
\hline \multirow{2}{*}{ Group } & \multirow{2}{*}{$\begin{array}{l}\text { Hybridization } \\
\text { variant }\end{array}$} & \multirow{2}{*}{$\begin{array}{l}\text { Weight at } \\
\text { slaughter, kg }\end{array}$} & \multirow{2}{*}{$\begin{array}{l}\text { Weight of hot } \\
\text { carcass, kg }\end{array}$} & \multirow{2}{*}{$\begin{array}{l}\text { Slaughter output } \\
\text { without skin, \% }\end{array}$} & \multicolumn{3}{|c|}{ Morphological content of half carcass, $\%$} \\
\hline & & & & & meat & fat & bones \\
\hline I & $\mathrm{LW} \times \mathrm{LW}$ & $101.2 \pm 2.36$ & $64.2 \pm 1.41$ & $62.8 \pm 2.23$ & $56.2 \pm 3.79$ & $32.5 \pm 1.50$ & $11.3 \pm 0.21$ \\
\hline II & $\mathrm{LW} \times \mathrm{D}$ & $100.6 \pm 1.58$ & $64.3 \pm 2.34$ & $64.0 \pm 3.17$ & $58.6 \pm 2.78$ & $29.1 \pm 1.21$ & $12.3 \pm 0.69$ \\
\hline III & $\mathrm{LW} \times \mathrm{DL}$ & $101.5 \pm 2.17$ & $64.8 \pm 2.81$ & $63.8 \pm 1.74$ & $61.9 \pm 2.51$ & $26.2 \pm 2.18^{*}$ & $11.9 \pm 0.25$ \\
\hline IV & $\mathrm{LW} \times \mathrm{FL}$ & $100.9 \pm 3.92$ & $65.1 \pm 1.32$ & $64.5 \pm 1.58$ & $58.9 \pm 4.31$ & $28.9 \pm 0.36^{*}$ & $12.2 \pm 0.35$ \\
\hline $\mathrm{V}$ & $\mathrm{LW} \times \mathrm{Bb} / \mathrm{w}$ & $102.4 \pm 1.23$ & $64.1 \pm 1.83$ & $62.6 \pm 2.80$ & $55.9 \pm 2.20$ & $32.0 \pm 0.75$ & $12.1 \pm 0.43$ \\
\hline VI & $\begin{array}{l}(\mathrm{LW} \times \mathrm{DL}) \times \\
\mathrm{D}\end{array}$ & $100.3 \pm 7.66$ & $69.1 \pm 5.53$ & $68.9 \pm 0.95^{*}$ & $60.9 \pm 2.32$ & $28.4 \pm 2.93$ & $10.7 \pm 0.52$ \\
\hline
\end{tabular}




\begin{tabular}{|c|c|c|c|c|c|c|c|}
\hline VII & $(\mathrm{LW} \times \mathrm{DL}) \times$ & $102.0 \pm 0.49$ & $70.5 \pm 0.90 * *$ & $69.1 \pm 0.92 * *$ & $61.4 \pm 2.64$ & $27.5 \pm 1.72$ & $11.1 \pm 0.56$ \\
\hline VIII & $\begin{array}{l}(\mathrm{LW} \times \mathrm{DL}) \times \\
\mathrm{MG}\end{array}$ & $101.6 \pm 0.75$ & $69.8 \pm 0.70 * *$ & $68.7 \pm 0.23 * *$ & $60.3 \pm 2.03$ & $28.8 \pm 1.93$ & $10.9 \pm 0.38$ \\
\hline IX & $\mathrm{LW} \times(\mathrm{D} \times \mathrm{FL})$ & $101.3 \pm 4.34$ & $69.3 \pm 2.95$ & $68.4 \pm 0.88 *$ & $60.6 \pm 0.65$ & $28.4 \pm 0.44$ & $11.0 \pm 0.30$ \\
\hline $\mathrm{X}$ & $\mathrm{LW} \times(\mathrm{FL} \times \mathrm{D})$ & $100.4 \pm 4.76$ & $68.4 \pm 4.41$ & $68.1 \pm 1.32 *$ & $59.3 \pm 0.75$ & $29.6 \pm 1.14$ & $11.1 \pm 0.30$ \\
\hline
\end{tabular}

Note: $-* \mathrm{P}<0.05 ; * * \mathrm{P}<0.01 ; * * * \mathrm{P}<0.001$.

The largest slaughter output in two-breed combinations was obtained from crosses of the genotype $-64.5 \%$. The two-breed hybrids $\mathrm{LW} \times \mathrm{FL}$ exceeded by its value purebred animals on $1.7 \%$, peers $\mathrm{LW} \times \mathrm{D}, \mathrm{LW} \times \mathrm{DL}$ and $\mathrm{LW}$ $\times \mathrm{B} \mathrm{b} / \mathrm{w}$ on $0.5 \%, 0.7 \%$ and $1.9 \%$, respectively.

Morphological composition of swine half carcass of investigated genotypes significantly differed in muscle, fat and bone tissues.

Two-breed hybrids LW $\times$ DL at slaughter in $100 \mathrm{~kg}$ were characterized by the highest output of meat in the carcass $-61.9 \%$. Animals of Large White breed yield to them in the content of meat on $5.7 \%$. By the highest content of body fat in carcass among two-breed hybrids, the animals $\mathrm{LW} \times \mathrm{B} \mathrm{b} / \mathrm{w}$ were distinguished $-32.0 \%$. The least amount of fat the carcass LW $\times \mathrm{DL}-26.2 \%$ contained, what was on $6.3 \%$ less than in purebred animals $(\mathrm{P}>0.95)$.

Analyzing the morphological composition of carcasses, it can be concluded that two-breed animals differed from their purebred analogues by high content of meat and less fat.

Three-breed yelts at slaughter in $100 \mathrm{~kg}$ were superior to purebred peers of Large White breed by mass of fresh carcass on $4.8-6.9 \mathrm{~kg}$ or on $7.5-10.8 \%$, by slaughter output - on $5.3-6.3 \%$. The yelts $(\mathrm{LW} \times \mathrm{DL}) \times \mathrm{DIb}$ were characterized by the best slaughter qualities; their slaughter output constituted $69.1 \%(\mathrm{P}>0.99)$, the fat content in the carcass $-27.5 \%$. Then follow the animals $(\mathrm{LW} \times \mathrm{DL}) \times \mathrm{D},(\mathrm{LW} \times \mathrm{DL}) \times \mathrm{MG}$. The comparative assessment of the compatibility of the breeds on the slaughter qualities indicates that the superiority on slaughter output, content of meat in the carcass and the least amount of fat in three-breed animals $(\mathrm{LW} \times \mathrm{DL}) \times \mathrm{MG}$ and $(\mathrm{LW} \times$ DL) $\times$ DIb is determined by the genotype of the investigated breeds.

Three-breed hybrids exceeded the purebred animals of Large White breed on meat output on $4.3 \%$ and two-breed animals - on $1.7 \%$. At slaughter of three-breed and two-breed animals the least amount of crude fat was obtained ( $28.5 \%$ and $29.1 \%$, respectively), mating sows of Large White breed with meat boars leads to significant reduction of the fat content in meat.

There were no significant differences between the groups on the bone output at slaughter in 100kg. However, it should be marked, that in two-breed variants, the yelts LW $\times \mathrm{D}$ and LW $\times$ FL were distinguished through the highest content of bones -12.3 и $12.2 \%$, what is on 1.0 and $0.9 \%$ more than the indicators of $\mathrm{LW} \times \mathrm{LW}$.

The obtained data and its analysis prove that three-breed animals had the highest output at slaughter in $125 \mathrm{~kg}$ $(\mathrm{LW} \times \mathrm{DL}) \times \mathrm{DIb}-72.2 \%$, then $(\mathrm{LW} \times \mathrm{DL}) \times \mathrm{D}-71.1 \%$, then follow $(\mathrm{LW} \times \mathrm{DL}) \times \mathrm{MG}-70.7 \%$ against $64.7 \%$ in control (Table 6).

Based on the results of monitoring of control slaughter we established the superiority of three-breed hybrids (LW $\times \mathrm{DL}) \times$ DIb in mass of fresh carcasses at slaughter in $125 \mathrm{~kg}$ to $8 \mathrm{~kg}$ or $9.8 \%$ compared with the control. The highest content of meat in half carcass at slaughter in $125 \mathrm{~kg}$ was in hybrids $(\mathrm{LW} \times \mathrm{DL}) \times \mathrm{DIb}(59.5 \%)$ what is higher than in the control group on $6.2 \%$.

Table 6. Slaughter qualities of young pigs at slaughter in $125 \mathrm{~kg}$

\begin{tabular}{|c|c|c|c|c|c|c|c|}
\hline \multirow[t]{2}{*}{ Group } & \multirow{2}{*}{$\begin{array}{l}\text { Hybridization } \\
\text { variant }\end{array}$} & \multirow{2}{*}{$\begin{array}{l}\text { Weight at } \\
\text { slaughter, } \mathrm{kg}\end{array}$} & \multirow{2}{*}{$\begin{array}{l}\text { Weight of half } \\
\text { carcass, } \mathrm{kg}\end{array}$} & \multirow{2}{*}{$\begin{array}{l}\text { Slaughter output } \\
\text { without skin, \% }\end{array}$} & \multicolumn{3}{|c|}{ Morphological content of half carcass, $\%$} \\
\hline & & & & & meat & fat & bones \\
\hline I & $\mathrm{LW} \times \mathrm{LW}$ & $125.3 \pm 1.28$ & $81.3 \pm 2.41$ & $64.7 \pm 1.23$ & $53.3 \pm 2.67$ & $35.6 \pm 1.47$ & $11.1 \pm 0.35$ \\
\hline II & $\mathrm{LW} \times \mathrm{D}$ & $125.0 \pm 1.60$ & $82.0 \pm 1.34$ & $65.6 \pm 1.26$ & $55.0 \pm 2.51$ & $33.3 \pm 1.18$ & $11.7 \pm 0.52$ \\
\hline III & $\mathrm{LW} \times \mathrm{DL}$ & $125.0 \pm 1.89$ & $82.4 \pm 1.71$ & $65.9 \pm 1.63$ & $57.7 \pm 2.71$ & $31.1 \pm 1.18$ & $11.2 \pm 0.28$ \\
\hline IV & $\mathrm{LW} \times \mathrm{FL}$ & $125.3 \pm 1.82$ & $81.7 \pm 1.32$ & $65.2 \pm 1.47$ & $57.0 \pm 2.24$ & $31.2 \pm 1.47$ & $11.8 \pm 0.48$ \\
\hline V & $\mathrm{LW} \times \mathrm{Bb} / \mathrm{w}$ & $125.1 \pm 1.27$ & $81.2 \pm 1.73$ & $64.9 \pm 1.78$ & $50.9 \pm 2.25$ & $37.3 \pm 2.64$ & $11.8 \pm 0.26$ \\
\hline VI & $(L W \times D L) \times D$ & $125.3 \pm 2.56$ & $89.1 \pm 2.42 *$ & $71.1 \pm 1.85^{*}$ & $59.1 \pm 2.68$ & $30.4 \pm 2.82 *$ & $10.5 \pm 0.43$ \\
\hline VII & $(\mathrm{LW} \times \mathrm{DL}) \times \mathrm{DIb}$ & $125.4 \pm 1.37$ & $89.3 \pm 2.19^{*}$ & $72.2 \pm 1.32 * *$ & $59.5 \pm 2.54$ & $29.6 \pm 2.62$ & $10.9 \pm 0.67$ \\
\hline
\end{tabular}




\begin{tabular}{|c|c|c|c|c|c|c|c|}
\hline VIII & $(\mathrm{LW} \times \mathrm{DL}) \times \mathrm{MG}$ & $125.6 \pm 1.75$ & $88.8 \pm 2.17$ & $70.7 \pm 1.43 * *$ & $58.7 \pm 2.81$ & $30.6 \pm 4.53$ & $10.7 \pm 0.32$ \\
\hline IX & $\mathrm{LW} \times(\mathrm{D} \times \mathrm{FL})$ & $125.0 \pm 2.24$ & $86.9 \pm 2.95$ & $69.5 \pm 1.78^{*}$ & $58.0 \pm 2.51$ & $31.2 \pm 2.62$ & $10.8 \pm 0.84$ \\
\hline $\mathrm{X}$ & $\mathrm{LW} \times(\mathrm{FL} \times \mathrm{D})$ & $125.0 \pm 1.56$ & $87.0 \pm 2.31$ & $69.6 \pm 1.33^{*}$ & $57.5 \pm 2.75$ & $31.6 \pm 2.25$ & $10.9 \pm 0.57$ \\
\hline
\end{tabular}

Note: $-{ }^{*} \mathrm{P}<0.05 ; * * \mathrm{P}<0.01 ; * * * \mathrm{P}<0.001$

On the content of fat in carcass, the animals of Large White breed exceeded three-breed analogues on 4-6\% in average.

For the comparative assessment of carcasses at slaughter an illustrative criterion is the ratio of the tissue: meat/bones - fleshing index and the meat/fat - leanness index (table 7).

Table 7. Carcass quality evaluation on correlation of tissue at slaughter in 100 and $125 \mathrm{~kg}$

\begin{tabular}{|c|c|c|c|c|c|}
\hline \multirow{4}{*}{ Group } & \multirow{4}{*}{$\begin{array}{l}\text { Hybridization } \\
\text { variant }\end{array}$} & \multicolumn{4}{|c|}{ Index } \\
\hline & & \multicolumn{2}{|c|}{$\begin{array}{l}\text { Fleshing } \\
\text { (meat/bones) }\end{array}$} & \multicolumn{2}{|c|}{$\begin{array}{l}\text { leanness } \\
\text { (meat/crude lard) }\end{array}$} \\
\hline & & at slaughter & & & \\
\hline & & in $100 \mathrm{~kg}$ & in $125 \mathrm{~kg}$ & in $100 \mathrm{~kg}$ & in $125 \mathrm{~kg}$ \\
\hline I & $\mathrm{LW} \times \mathrm{LW}$ & 4.97 & 4.8 & 1.73 & 1.49 \\
\hline II & $\mathrm{LW} \times \mathrm{D}$ & 4.75 & 4.70 & 2.01 & 1.65 \\
\hline III & $\mathrm{LW} \times \mathrm{DL}$ & 5.20 & 5.15 & 2.36 & 1.85 \\
\hline IV & $\mathrm{LW} \times \mathrm{FL}$ & 4.83 & 4.91 & 2.04 & 1.85 \\
\hline V & $\mathrm{LW} \times \mathrm{Bb} / \mathrm{w}$ & 4.62 & 4.34 & 1.74 & 1.37 \\
\hline VI & $(\mathrm{LW} \times \mathrm{DL}) \times \mathrm{D}$ & 5.69 & 5.63 & 2.14 & 1.94 \\
\hline VII & $(\mathrm{LW} \times \mathrm{DL}) \times \mathrm{DIb}$ & 5.53 & 5.46 & 2.23 & 2.01 \\
\hline VIII & $(\mathrm{LW} \times \mathrm{DL}) \times \mathrm{MG}$ & 5.53 & 5.48 & 2.09 & 1.92 \\
\hline IX & $\mathrm{LW} \times(\mathrm{D} \times \mathrm{FL})$ & 5.51 & 5.37 & 2.13 & 1.86 \\
\hline $\mathrm{X}$ & $\mathrm{LW} \times(\mathrm{FL} \times \mathrm{D})$ & 5.34 & 5.28 & 2.00 & 1.82 \\
\hline
\end{tabular}

Note: $-* \mathrm{P}<0.05 ; * * \mathrm{P}<0.01 ; * * * \mathrm{P}<0.001$

The findings prove that at slaughter in $100 \mathrm{~kg}$ on the fleshing index and on the leanness index the leaders were two-breed animals LW $\times$ DL and three-breed $(\mathrm{LW} \times \mathrm{DL}) \times \mathrm{D}$ and $(\mathrm{LW} \times \mathrm{DL}) \times \mathrm{DIb}$. It is significant that with increased live weight at slaughter leanness and muscle mass indices reduce; it means that the animal carcasses at fattening swine up to high grade become lardy.

A completed study of the chemical composition of the longissimus dorsi in young pigs revealed that indicators such as moisture, fat, protein content depend on the genotype of the pigs and slaughter terms.

An important component of the meat is water. On the basis of the received data, in the sample of meat animals with increasing weight at slaughter we observed the reduction of total moisture content.

The analysis of physical and chemical properties of meat revealed that in young pigs of all experimental groups in the sample of meat at slaughter of $125 \mathrm{~kg}$, moisture content was less than in young pigs with the weight before slaughter $100 \mathrm{~kg}$ of similar groups, on $1.3 ; 1.2 ; 1.1 ; 1.0 ; 0.8 ; 1.1 ; 1.1 ; 1.2 ; 1.3$ and $1.0 \%$, respectively (tables 8 , 9).

Table 8. Chemical composition of meat in two- and three-breed crossing at slaughter in $100 \mathrm{~kg}$

\begin{tabular}{|c|c|c|c|c|c|c|c|}
\hline \multirow[b]{2}{*}{ Group } & \multirow{2}{*}{$\begin{array}{l}\text { Hybridization } \\
\text { variant }\end{array}$} & \multicolumn{6}{|l|}{ Indicator } \\
\hline & & $\begin{array}{l}\text { total } \\
\text { moisture, \% }\end{array}$ & $\begin{array}{l}\text { dry matter, } \\
\%\end{array}$ & $\begin{array}{l}\text { fat, } \\
\%\end{array}$ & $\begin{array}{l}\text { protein, } \\
\%\end{array}$ & $\begin{array}{l}\text { waterbinding } \\
\text { ability, \% }\end{array}$ & $\mathrm{pH}$ \\
\hline I & $L W \times L W$ & $72.1 \pm 0.54$ & $27.9 \pm 0.54$ & $4.90 \pm 0.18$ & $22.4 \pm 0.26$ & $61.0 \pm 0.80$ & $5.65 \pm 0.11$ \\
\hline II & $\mathrm{LW} \times \mathrm{D}$ & $72.6 \pm 0.33$ & $27.4 \pm 0.33$ & $3.70 \pm 0.13^{* * *}$ & $23.1 \pm 0.22$ & $65.7 \pm 0.60 * *$ & $5.65 \pm 0.05$ \\
\hline III & $\mathrm{LW} \times \mathrm{DL}$ & $72.9 \pm 0.61$ & $27.1 \pm 0.61$ & $3.61 \pm 0.18^{* * *}$ & $23.1 \pm 0.54$ & $65.3 \pm 0.91 * *$ & $5.58 \pm 0.02$ \\
\hline IV & $\mathrm{LW} \times \mathrm{FL}$ & $72.7 \pm 0.42$ & $27.3 \pm 0.42$ & $3.72 \pm 0.12 * * *$ & $23.5 \pm 0.81$ & $65.7 \pm 0.33 * * *$ & $5.61 \pm 0.01$ \\
\hline V & $\mathrm{LW} \times \mathrm{Bb} / \mathrm{w}$ & $70.6 \pm 0.18$ & $29.4 \pm 0.18$ & $4,17 \pm 0.22^{*}$ & $22.0 \pm 0.41$ & $62.7 \pm 0.43$ & $5.63 \pm 0.08$ \\
\hline VI & $(\mathrm{LW} \times \mathrm{DL}) \times \mathrm{D}$ & $72.8 \pm 0.62$ & $27.2 \pm 0.62$ & $2.59 \pm 0.12 * * *$ & $24.1 \pm 0.38^{*}$ & $66.0 \pm 0.56^{* * *}$ & $5.69 \pm 0.22$ \\
\hline
\end{tabular}




\begin{tabular}{llllllll}
\hline VII & $(\mathrm{LW} \times \mathrm{DL}) \times \mathrm{DIb}$ & $73.2 \pm 0.61$ & $26.8 \pm 0.61$ & $2.50 \pm 0.18 * * *$ & $24.8 \pm 0.54 *$ & $67.3 \pm 0.91 * *$ & $5.71 \pm 0.02$ \\
VIII & $(\mathrm{LW} \times \mathrm{DL}) \times \mathrm{MG}$ & $73.6 \pm 0.33$ & $26.4 \pm 0.33$ & $2.55 \pm 0.13 * * *$ & $24.5 \pm 0.22 * *$ & $67.7 \pm 0.60 * *$ & $5.75 \pm 0.05$ \\
$\mathrm{IX}$ & $\mathrm{LW} \times(\mathrm{D} \times \mathrm{FL})$ & $73.3 \pm 0.76$ & $26.7 \pm 0.76$ & $2.57 \pm 0.13 * * *$ & $24.1 \pm 0.59$ & $66.7 \pm 0.88 * *$ & $5.83 \pm 0.20$ \\
$\mathrm{X}$ & $\mathrm{LW} \times(\mathrm{FL} \times \mathrm{D})$ & $73.4 \pm 0.66$ & $26.6 \pm 0.66$ & $2.58 \pm 0.22 * * *$ & $24.4 \pm 0.50$ & $66.3 \pm 0.28 *$ & $5.79 \pm 0.03$ \\
\hline
\end{tabular}

Note: $-* \mathrm{P}<0.05 ; * * \mathrm{P}<0.01 ; * * * \mathrm{P}<0.001$

Table 9. Chemical composition of meat in two- and three-breed crossing at slaughter in $125 \mathrm{~kg}$

\begin{tabular}{cccccccc}
\hline \multirow{2}{*}{ Group } & Hybridization & \multicolumn{5}{c}{ Indicator } \\
\cline { 3 - 7 } & variant & total moisture, & drymatter, $\%$ & fat, & protein, & waterbinding & pH \\
\cline { 3 - 7 } I & LW $\times$ LW & $70.8 \pm 0.14$ & $29.2 \pm 0.14$ & $5.73 \pm 0.18$ & $22.6 \pm 0.12$ & $59.8 \pm 0.78$ & $5.45 \pm 0.12$ \\
II & LW $\times$ D & $71.4 \pm 0.19$ & $28.6 \pm 0.19$ & $4.33 \pm 0.21^{* * *}$ & $23.5 \pm 0.10$ & $64.4 \pm 0.53^{* *}$ & $5.48 \pm 0.07$ \\
III & LW $\times$ DL & $71.8 \pm 0.20$ & $28.2 \pm 0,20$ & $4.26 \pm 0.19^{* * *}$ & $23.6 \pm 0.16$ & $63.9 \pm 0.85^{* *}$ & $5.48 \pm 0.11$ \\
IV & LW $\times$ FL & $71.7 \pm 0.15$ & $28.3 \pm 0.15$ & $4.39 \pm 0.12^{* * *}$ & $23.9 \pm 0.17$ & $64.7 \pm 0.52^{* * *}$ & $5.42 \pm 0.05$ \\
V & LW $\times \mathrm{Bb} / \mathrm{w}$ & $69.8 \pm 0.25$ & $30.2 \pm 0.25$ & $4.97 \pm 0.18^{* *}$ & $22.4 \pm 0.18$ & $61.4 \pm 0.62$ & $5.44 \pm 0.12$ \\
VI & $(\mathrm{LW} \times \mathrm{DL}) \times \mathrm{D}$ & $71.7 \pm 0.17$ & $28.3 \pm 0.17$ & $3.03 \pm 0.18^{* * *}$ & $24.5 \pm 0.15$ & $64.7 \pm 0.61^{* *}$ & $5.49 \pm 0.09$ \\
VII & $(\mathrm{LW} \times \mathrm{DL}) \times \mathrm{DIb}$ & $72.1 \pm 0.24$ & $27.9 \pm 0.24$ & $2.93 \pm 0.23^{* * *}$ & $25.3 \pm 0.18$ & $65.9 \pm 0.74^{* * *}$ & $5.46 \pm 0.07$ \\
VIII & $(\mathrm{LW} \times \mathrm{DL}) \times \mathrm{MG}$ & $72.4 \pm 0.29$ & $27.6 \pm 0.29$ & $3.01 \pm 0.14^{* * *}$ & $24.9 \pm 0.22$ & $66.3 \pm 0.58^{* * *}$ & $5.44 \pm 0.08$ \\
IX & $\mathrm{LW} \times(\mathrm{D} \times \mathrm{FL})$ & $72.0 \pm 0.30$ & $28.0 \pm 0.30$ & $3.03 \pm 0.19^{* * *}$ & $24.6 \pm 0.19$ & $65.4 \pm 0.68^{* * *}$ & $5.48 \pm 0.11$ \\
$\mathrm{X}$ & $\mathrm{LW} \times(\mathrm{FL} \times \mathrm{D})$ & $72.4 \pm 0.20$ & $27.6 \pm 0.20$ & $3.02 \pm 0.18^{* * *}$ & $24.9 \pm 0.20$ & $64.9 \pm 0.46^{* * *}$ & $5.44 \pm 0.06$ \\
\hline
\end{tabular}

Note: $-* \mathrm{P}<0.05 ; * * \mathrm{P}<0.01 ; * * * \mathrm{P}<0.001$

The muscle tissue of three-breed hybrids $(\mathrm{LW} \times \mathrm{DL}) \times \mathrm{MG}$ had the highest amount of moisture in all the studied periods. Their superiority over their peers in the control group by size of the studied indicator was at slaughter at $100 \mathrm{~kg}-1.5 \%$, at slaughter at $125 \mathrm{~kg}-1.6 \%$.

Fat content has a significant impact on the nutritional value of meat, because it has a high energetic value and gives the pleasant taste to meat products. The fat content of $3.8-4.0 \%$ is considered as normal, and allows the meat to save its technological properties and high qualities.

The lowest fat content found in two-breed hybrids $\mathrm{LW} \times \mathrm{DL}-3.61$ and $4.26 \%$ and three-breed hybrids (LW $\times \mathrm{DL}$ ) $\times \mathrm{DIb}-2.50$ and $2.93 \%$ at slaughter at 100 and $125 \mathrm{~kg}$ respectively, what is 1.29 and $1.47 \%$ less compared to purebred animals at slaughter in 100 and $125 \mathrm{~kg}$ and 2.4 and $2.8 \%$ for three-breed hybrids. Therefore, meat of the hybrids $\mathrm{LW} \times \mathrm{DL}$ and $(\mathrm{LW} \times \mathrm{DL}) \times \mathrm{DIb}$ is quite leanness.

The protein content in the meat of young animals of all groups increased slightly with age. The three-breed hybrids $(\mathrm{LW} \times \mathrm{DL}) \times \mathrm{DIb}$ were characterized by the highest amount of protein and fat. At slaughter at $100 \mathrm{~kg}$ of live weight, two-breed hybrids $\mathrm{LW} \times \mathrm{D}, \mathrm{LW} \times \mathrm{DL}$ and $\mathrm{LW} \times \mathrm{FL}$ were superior to their peers of Large White breed on the content of protein in the average of $0.83 \%$, at slaughter in $125 \mathrm{~kg}$ to $1.07 \%$ and yield by quantity of fat on 1.22 and $1.40 \%$, respectively.

One of the main indicators of the meat is water-binding ability to illustrate the ability of muscle proteins to hydration. High content of bound water in meat testifies to its juiciness and best technological properties. It is known that water-binding ability of pork is divided into 3 categories: high (67\% and more), normal (53-66 \%) and low (52\% and less) (Rybalko V. et al, 2005).

It was established that the content of bound water in meat of purebred and hybrid young pigs was in the norm 61.0-67.7\%.Therefore, the meat of these animals meets the requirements for normal qualities of pork. The highest water-binding ability of meat was observed in hybrids (LW $\times \mathrm{DL}) \times \mathrm{MG}-67.7 \%$ at slaughter in $100 \mathrm{~kg}$ and $66.3 \%$ at slaughter in $125 \mathrm{~kg}$, which was significantly higher than in the animals in the control group on $6.7 \%$ $(\mathrm{P}>0.95)$ and $6.5 \%$.

One of the main indicators of the quality of meat is $\mathrm{pH}$. $\mathrm{pH}$ indicates the glycolysis degree in muscle tissue, that is suitable for the storage of meat and cooking. Hydrogen-ion concentration in meat depends on the content of 
glycogen and lactic acid in the muscles at the time of slaughter, and as a result, is a derivative of the physiological condition of the animal before slaughter, and also displays the flow of after-slaughter processes in the carcass(Sheiko I.P. et al., 2008, Sevčílkoví S. et al, 2002).

In meat of healthy animals in 12 hours after their slaughter, $\mathrm{pH}$ ranges from 5.6 to 7.2.The normal value of $\mathrm{pH}$ is from 5.4 to 6.3. In our research, active acidity of meat of young pigs in all experimental groups was within the rates and was at slaughter in $100 \mathrm{~kg} 5.65-5.83$ units; at slaughter in $125 \mathrm{~kg}-5.42-5.48$ units.

\section{Discussion}

Comprehensive assessment of fattening qualities of pigs with different genotypes indicates the efficiency of hybridization of sows of Large White breed with boars of Dutch Landrace and Finnish Landrace breeds and also sows LW $\times$ DL with Irish Duroc boars and with synthetic MG boars. It allows increasing production of pork with high consume qualities.

Summarizing of obtained data on three-breed hybridization with hybrid boars and sows using shows that advantage when using of hybrid sows in comparison with hybrid boars reveals in increasing their daily average growth while fattening by $57.7 \mathrm{~g}$ in average in group. Offspring of hybrid sows has an advantage over their contemporaries from hybrid boars in early ripeness and feed consumption per $1 \mathrm{~kg}$ of growth in average in group 5 days and 0.09 feeding units, respectively.

Breeding of LW $\times$ DL pigs were notable for good early ripening (182.1 days), high daily average growth (735.8 $\mathrm{g}$ ), lower feed consumption per $1 \mathrm{~kg}$ of growth among two-breed variants. Hybrids $(\mathrm{LW} \times \mathrm{DL}) \mathrm{x} \mathrm{MG}$ reached $100 \mathrm{~kg}$ of live weight at younger age and had maximum daily average growth -167.8 days and $821.9 \mathrm{~g}$ among three-breed variants.

Three-breed hybrids excel purebred Large White pigs in meat receiving by $4.3 \%$ and two-breed hybrids - by $1.7 \%$. Three-breed and two-breed hybrids gave the lowest amount of fat: $28.5 \%$ и $29.1 \%$, respectively.

The two-breed $\mathrm{LW} \times \mathrm{DL}$ and three-breed $(\mathrm{LW} \times \mathrm{DL}) \times \mathrm{D}$ and $(\mathrm{LW} \times \mathrm{DL}) \times \mathrm{DIb}$ animals led by fleshing and leanness indices at slaughter in the 100 and $125 \mathrm{~kg}$.

Therefore, obtained results of research are evidence of that two-breed hybrids LW $\times$ DL and three-breed hybrids $(\mathrm{LW} \times \mathrm{DL}) \times \mathrm{DIb}$ had higher meat productivity and good fattening and slaughtering qualities both as at fattening up to $100 \mathrm{~kg}$, as to $125 \mathrm{~kg}$ of live weight.

\section{Conclusions}

1. The animals LW $\times$ DL had the highest precocity among two-breed hybrids; reaching $100 \mathrm{~kg}$ they surpassed their peers from other experienced groups on $2.1-10.2$ days. Among three-breed hybrids, animals $(\mathrm{LW} \times \mathrm{DL}) \times$ MG had the highest precocity, they surpassed their peers on $0.7-5.6$ days. A similar trend was observed when animals reached 125 kgoflive weight.

2. The highest slaughter output was obtained from two-breed hybrids $\mathrm{LW} \times \mathrm{FL}$ and amounted to $64.5 \%$ at slaughter in $100 \mathrm{~kg}$, which is higher than from two-breed hybrids of other groups on $0.7-1.9 \%$. Themass of hot carcass in two-breed hybrids LW $\times$ FLwas higher compared with their peers in other test groups on $0.3-1.0 \mathrm{~kg}$. In three-breed hybrid gilts $(\mathrm{LW} \times \mathrm{DL}) \times \mathrm{Dib}$ were characterized by the best slaughter qualities, their slaughter output accounted for $69.1 \%$, and mass of hot carcasses $-70.5 \mathrm{~kg}$.

3. The use of two-breed and three-breed hybridization contributed improvement of meat qualities: the muscle eye area in gilts LW $\times$ DL amounted to $46.2 \mathrm{~cm}^{2}$, what is on $0.9-7.6 \mathrm{~cm}^{2}$ higher than in their peers, and the hock mass amounted to $10,9 \mathrm{~kg}$, what is in compare to their peers $0.1-2.2 \mathrm{~kg}$, respectively. In gilts $(\mathrm{LW} \times \mathrm{DL}) \times \mathrm{DIb}$, the muscle eye area amounted to $63.5 \mathrm{~cm}^{2}$, what is on $2.1-5.0 \mathrm{~cm}^{2}$ higher than in their peers, and hock mass amounted to $12.4 \mathrm{~kg}$, what is on $0.3-2.4 \mathrm{~kg}$ higher that in their peers.

\section{References}

Babailova, G. P., Zhdanov, S. L., \& Dubinin, A. A. (2010). Chemical composition of meat of large white pigs breed. Materials of the international scientific-practical conference dedicated to the 80th anniversary of the Vyatka State Academy, 11- 14.

Bazhov, G. M. (2006). Breeding swine production. Saint Petersburg, p. 384.

Bekenev, V. A. (2012) Technologies of breeding and keeping swine. Saint Petersburg, p. 416.

Birta, G. (2008) Meat and lard quality of pigs of different breeds. Swine production, 5, 11-12.

Burmistrov, V., \& Pustovit, I. (2005). Physical and chemical composition of muscle and adipose tissue in pigs of 
different genotypes. Swine production, 2, 14-16.

DuninI, M., Garai, V. V., \& Pavlova, S. V. (2009). State, development strategy of pedigree base and hybridization system in pig-breeding in Russia. Zootechny, 1, 4-8.

Kabanov, V., \& Titov, I. (2013). Yopkshire, Landrace, Duroc and hybrids. Russian livestock. Special issue, p. 19.

Kortz, J., \& Czarnecki, R. (1999). Effects of genetic line on the quality of meat produced by purebred Polish large white (PLW) swine and by PLW crosses with Czech genetic lines. Adv. Agr. Sci., 6(2), 93-98.

Lesley, J. F. (1982) Genetic base of agriculture animal selection. Publishing House Kolos, p. 391.

Matoušk, V., Kernerová, N., \& Václavovsý, J. (1997). Analýzakvalitymasa u hybridnípopuaceprasat. Zivoc. Zyroba, 42(11), 511-515.

Mucami, H., \& Jamada, J. (1992). Economical efficiencies of crossbreeding systems in pigs. Bulletin of National Institute of Animal Industry, 38, 5-19.

Okolyshev, S. (2008). Meat-lard qualities of swine. Animal husbandry of Russia, 4, 43- 45.

Ovchinnikov, A. V., \& Zatsarinin, A. A. (2013). Fattening and slaughtering qualities of pigs of different genotypes when fattening up to high weight standards. Zootechny, 2, 18-20.

Perevoiko, Zh. A. (2005). Fattening and meat quality of purebred and crossbred swine fattening up to $100 \mathrm{~kg}$. Proceedings of Russian scientific conference of scientists and specialists. pp. 169-172.

Pogodaev, V. A., \& Peshkov, A. D. (2011). Quality of muscle and adipose tissue in purebred and hybrid pigs. Swine Production, 4, 24-26.

Rybalko, V. P., Bankovska, I. B., \& Getia, A. A. (2005). Meat quality management under the intensive breeding of swine. Agricultural Journal, 4-5, 28-29).

Rybalko, V., Birta, G., \& Burgu, I. U. (2011). The quality of pork meat in different genotypes. Swine production.No. 6. pp.23-25.

Sevčílkoví, S., Koucký, M., \& Laštovková, J. (2002). Meat performance and meat quality in different genotypes of F1 generation gilts.Czech J. Anim. Sci., 47(9), 395-400.

Sheiko, I. P., Fedorenkova, L. A., \& Chramchenko, N. M. (2008). Comparative assessment of quality of pork in young animals of different genotypes. Swine Farm, 3, 10-13.

Zhebrovskii, L. S. (2002). Animal selection. SPb.: Publishing house Lan, p. 256. Saint-Petersburg.

\section{Copyrights}

Copyright for this article is retained by the author(s), with first publication rights granted to the journal.

This is an open-access article distributed under the terms and conditions of the Creative Commons Attribution license (http://creativecommons.org/licenses/by/3.0/). 